Int. J. Electrochem. Sci., 15 (2020) 3825 - 3835

\title{
Effect of Marble Dust and Silica Fume admixtures replaced in ordinary Portland cement on corrosion behavior of carbon steel in the concrete after exposure to $5 \mathrm{wt} \% \mathrm{NaCl}$ solution
}

\author{
Shengpin Liu ${ }^{1}, \mathrm{Wu} \mathrm{Zhao}^{2, *}$ \\ ${ }^{1}$ School of Architecture and Urban planning, Shandong Jianzhu University, Jinan, 250100 ,China \\ ${ }^{2}$ College of Water Conservancy and Civil Engineering, Shandong Agriculture University, Tai' an \\ 271000, China \\ *E-mail: wuzhao@sdau.edu.cn, wuzhao_2000@163.com
}

doi: $10.20964 / 2020.05 .51$

Received: 5 January 2020 / Accepted: 20 February 2020 / Published: 10 April 2020

\begin{abstract}
Recent studies show that corrosion resistivity of reinforced concrete can be enhanced by modifying the structure of concrete, especially cement replacement by mineral admixtures. In this work, the effect of partial replacement of ordinary Portland cement (OPC) on corrosion behavior of carbon steel reinforced concrete in $5 \mathrm{wt} \% \mathrm{NaCl}$ solution were investigated. The OPC was partially replaced by a combination of marble dust (MD) and silica fume (SF) admixtures. Potentiodynamic polarisation measurement, electrochemical impedance spectroscopy, cyclic voltammetry and water absorption test were used to evaluate the corrosion behavior of carbon steel rebar. The electrochemical results showed that the sample with MD $\left(30 \mathrm{~kg} / \mathrm{m}^{3}\right)$ and $\mathrm{SF}\left(30 \mathrm{~kg} / \mathrm{m}^{3}\right)$ cement replacement had higher corrosion resistance and potential than all the others. The absorption results revealed that the SF30MD30 sample significantly changed the water absorption of reinforced concrete. The scanning electron microscopy images of carbon steel surface showed that low corrosion products and narrow pits appeared on the surface of SF30MD30 sample which was in accordance with the results obtained from electrochemical experiments. These findings indicated that mineral admixtures had resulted in a reduction of hydroxide ion concentrations which had led to an increase in passivation of the reinforcement steel and an improved corrosion resistance.
\end{abstract}

Keywords: Corrosion resistance; Marble dust and silica fume admixtures; Ordinary Portland cement; carbon steel rebar; Electrochemical technique; Water absorption

\section{$\underline{\text { FULL TEXT }}$}

(C) 2020 The Authors. Published by ESG (www.electrochemsci.org). This article is an open access article distributed under the terms and conditions of the Creative Commons Attribution license (http://creativecommons.org/licenses/by/4.0/). 